\title{
Van Depremini Yaşayan Ortaöğretim Öğrencilerinin Travmadan Etkilenme ve Umutsuzluk Düzeylerinin İncelenmesi
}

\author{
Fuat TANHAN*
}

\author{
Ferhat KARDAŞ ${ }^{* *}$
}

\begin{abstract}
Özet
Bu çalışmanın amacı Van depremini yaşayan ortaöğretim öğrencilerinin travmadan etkilenme ve umutsuzluk düzeylerinin incelenmesidir. Araştırma ilişkisel ve betimsel tarama modelleriyle gerçekleştirilmiştir. Çalışmanın örneklemi seçkisiz yöntemle belirlenen 185'i kız, 140'1 erkek olmak üzere toplam 325 öğrenciden oluşmaktadır. Veri toplama araçları olarak Çocuklar İçin Travma Sonrası Stres Tepki Ölçeği (ÇTSSBTÖ), Beck Umutsuzluk Ölçeği (BUÖ) ve katılımcılara ait demografik değişkenleri öğrenmek için Katılımc1 Bilgi Formu (KBF) kullanılmıştır. Araştırmada katılımcıların travma puanlarının normal dağılım gösterdiği ve umutsuzluk puanlarının normal dağılım göstermediği bulunmuştur. Verilerin analizinde parametrik olmayan yöntemler kullanılmıştır. Veri analizinde ki kare testi, iki aşamalı kümeleme analizi ve korelasyon analizlerinden spearman'ın rho katsayısı kullanılmıştır. Araştırma bulgularına göre katılımcıların travma düzeyleri ile umutsuzluk düzeyleri arasında pozitif yönde anlamlı bir ilişki bulunmaktadır. Diğer yandan bireylerin düşük düzey, orta düzey ve yüksek düzey travmadan etkilenmeleri ile cinsiyet, depremde yakın kaybı yaşama, ve lise türü değişkenleri arasında anlamlı ilişkiler bulunmaktadır. Katılımcıların düşük, orta ve yüksek umutsuzluk düzeyleri lise türü arasında anlamlı ilişki bulunmuştur. Araştırma sonuçlarına göre umutsuzluk, cinsiyet, depremde yakın kaybı yaşama travmadan etkilenme düzeyi için risk faktörleri arasındadır. Travmatik olaylara maruz kalan bireylere yönelik geliştirilen müdahale programlarında bu değişkenlerin göz önünde bulundurulması yararlı olacaktır.
\end{abstract}

Anahtar Kelimeler: Travma, deprem, ergen, umutsuzluk, TSSB.

\section{Investigating Hopelessness and Trauma Levels Of High School Students Exposed To The Van Earthquake}

\begin{abstract}
The purpose of this research is investigating the hopelessness and trauma level of adolescents experiencing the Van earthquake. This research is in general survey model. The research sample consists of 185 female and 141 male students determined randomly. In the study Child Posttraumatic Stress Reaction Index (CPTS-RI), Beck Hopelessness Scale (BHS) and an information form are used for data collection. When testing with Kolmogrov test it was found that PTSD scores shows a normal distribution and BHS scores does not show normal distribution. For this reason non parametric analysis methods were used. In data analysis chi-square test, two-step cluster analysis and spearman rho correlation analysis were used. It is found that participants' levels of trauma has a significant positive relationship with their hopelessness levels. Participants' low level, medium level and high levels of trauma were found to be significantly related with the va-
\end{abstract}

\footnotetext{
* Yrd. Doç. Dr. Yüzüncü Yıl Üniversitesi Eğitim Fakültesi Eğitim Bilimleri Bölümü Psikolojik Danışma ve Rehberlik ABD, fuad65@gmail.com

${ }^{* *}$ Araş. Gör. Ankara Üniversitesi Eğitim Bilimleri Fakültesi, Psikolojik Danışma ve Rehberlik
} 
riables of being female, having loss of family members in the earthquake and type of high school. Besides participants' low level, medium level and high levels of hopelessness level was found to be significantly related to the participants' trauma levels and type of high school. According to the research results level of hopelessness, being female, having loss of family members in an earthquake are risk factors for level of being effected from a traumatic life event. These risk factors for trauma and hopelessness should be taken into consideration in the intervention studies for adolescents.

Keywords: Trauma, earthquake, adolescents, hopelessness, PTSD

\section{GíRIş}

Ruh sağlığı alanında travma yaşantıları ve bu yaşantıların psikolojik etkileri sıklıkla çalışılan ve önem verilen konulardan biridir. Depremlerin, savaşların, kazaların ve çeşitli doğal felaketlerin insanlar üzerinde kısa ve uzun vadeli ciddi etkilerinin olduğu görülmektedir. İnsanların yaşadıkları bu travmatik olaylara verdikleri tepkileri belirlemek, bu tepkilerle ilgili değişkenler konusunda farkındalığa sahip olmak yaşanan travmatik olaylara hazırlıklı olmak ve bunlara etkin müdahale programları geliştirebilmek açısından büyük önem arz etmektedir.

Yaşamın normal bir akışı vardır. Bu akış içinde insanlar çeşitli stresli durumlara maruz kalabilirler. Günlük yaşamın akışı içinde gerçekleşen stresli durumlar belli bir denge içinde karşılık bulurlar ve ve bireyler genel olarak bu stresörlere karşı bir tepki dağarcığına sahiptir. Ancak travmatik yaşantılar bu tepki dağarcığını alt üst eder, bireyin başa çıkma mekanizmalarını devre dışı bırakır. Bu yönüyle yaşanan felaketler ve travmatik deneyimler yaşamın normal akışı sırasında karşılaşılan stresli durumlardan farklılaşmaktadır (Yüksel, 2000). Travmatik yaşantılar olağan dışıdır, bireyin hayata olağan uyumunu alt üst eder. Siradan talihsizliklerin tersine travmatik olaylar genel olarak hayata ya da beden bütünlügüne yönelik tehditler içerir ya da şiddet ve ölümle yakından ilişkilidir. Psikolojik travma genel anlamda bir güçsüzlük acısıdır. Travma anında birey altüst edici bir kuvvetin etkisinde çaresizdir. $\mathrm{Bu}$ nedenle travmatik olaylar insanlara kontrol, bağ kurma ve anlam duygusu veren olağan davranış sistemini alt üst eder (Herman, 1992) .

Travmatik olaylar insan eliyle gerçekleşenler ve doğal yollarla gerçekleşenler olmak üzere iki başlıkta incelenebilir. Deprem, sel, kasırga, yanardağ patlamaları doğal yollarla; savaşlar, kitle katliamları, taciz-tecavüz olayları, kazalar, işkence, terör olayları insan eliyle gerçekleşen travma yaşantılarıdır. Travma yaşantıları içinde depremler ayrı bir yere sahiptir. Depremler ansızın meydana gelmeleri, öngörülmezliği, yol açtıkları yıkım, ölüm ve yaralanmalar gibi pek çok sorun alanını ortaya çıkarırlar. Bunların yanında artçı sarsıntılar nedeniyle kronik etkiler de yaratabilmeleri nedeniyle depremler diğer afetlerden farklılaşmaktadır (Sabuncuoğlu ve ark., 2003). Depremler en fazla ölüme yol açan doğal afetlerdendir ve ülkemiz topraklarının \% 92'si, nüfusunun \% 95'i, endüstriyel yatımlarının \% 75'i deprem kuşağı üzerindedir (Yavuz 2004; akt: Dizer, 2008). Ülkemizde son yaşanan Van depremi örneğinde görüldüğü gibi orta şiddetin üstündeki depremler binlerce insanın ölmesine, yaralanmasına, evsiz kalmasına, yakınlarını kaybetmesine, işsiz kalmasına neden olmaktadır (Ma ve diğ., 2011; Doğan, 2011; Tuna, Parin ve Tanhan, 2012)

Travmalara karşı geliştirilen tepkilerden bir kısmı bireyi travmanın olumsuz etkilerinden korumanın yanı sıra güçlendire de bilir. Buna karşın, kimi etkiler de bireyin işlevselliğini bozabilmektedir. $\mathrm{Bu}$ nedenle bireyin işlevselliğinin bozulması travmanın etkilerini ve ciddiyet düzeyini anlamada bir ölçüt olarak değerlendirilmektedir. Verilen tepkilerden kişinin işlevlerini bozanlar ilk bir ay için Akut 
Stres Bozukluğu (ASB), 1 aydan sonraki süreçler için Travma Sonrası Stres Bozukluğu (TSSB) olarak seslendirilmektedir. Gerçek bir ölüm ya da ölüm tehdidi, ağır yaralanma, bireyin fiziksel bütünlüğünü tehdit eden bir durumla karşılaşması, böyle bir duruma tanık olma gibi ağır travmatik olaylardan sonra ortaya çıkabilen; olayı yeniden yaşama, istenmeden akla gelen düşünce ve görüntüler, kaçınma ve aşırı fizyolojik uyarılmışlık gibi semptomlar travma sonrası stres bozukluğu (TSSB) olarak tanılanmaktadır DSM-IV TR, 2007).

Yeteri kadar tehdit edici bir olayla karşılaşan her birey travma sonrası stres bozukluğu yaşayabilir. Ancak yaşanan her travmatik olay travmaya neden olmaz. Yapılan araştırmalarda bireylerin daha fazla travmatize olmasina neden olan bazı faktörler belirlenmiştir. İrrasyonel düşünceler bunların başında gelir (Beck, 1964). Bunun yanı sıra, bazı araştırmalarda yaşanan olayın birey için öznel anlamı olması, karşı karşıya kalma süresinin uzaması, hazırlıksız yakalanma, olayın katastrofik olması, ölüm tehdidi içermesi, fiziksel yaralanma ile birlikte olması, gaddarlık ve kişide suçluluk duygusu uyarması, kişinin köşeye sıkıştırılmışlığı hissetmesi gibi değişkenler stresörün etki şiddetini arttıran faktörlerdir (Özgen ve Aydın, 1999).

Travmanın etkileriyle bağlantılı olarak ele alınan değişkenlerden biri de umutsuzluktur. Bireyin kendisine ve geleceğe ilişkin olumsuz düşüncelerinin bir yansıması olarak ortaya çıkan, bireyin olumsuz düşüncelerinin biçimlendirdiği umutsuzluk (Silbert ve Berry, 1991); çok istendik sonuçların gerçekleşmeyeceği ya da kötü sonuçların elde edileceği ve hiçbir şeyin bu durumu değiştirmeyeceğine dönük beklentileri (Metalsky ve ark., 1993), ifade eder. Diğer bir ifadeyle umutsuzluk, kişinin iyilik halinden yoksunluğunu, isteksizliğini ve amaçsızlığını içermektedir. Bu yönüyle yaşam olaylarının olumsuz şekilde algılandığı, şimdiki ve gelecek zamana ilişkin negatif bilişsel bir değerlendirmedir (Ehtiyar ve Üngüren, 2009). Bu bağlamda olumsuz yaşam olayları ile bunlara ilişkin olumsuz, yerleşik ve genelleştirilmiş çıkarsamalar, umutsuzluk duygularını besleyen başlıca etmenler arasında değerlendirilebilir (Yerlikaya, 2006). Umutsuzluğun temeli, geçmişte yaşanmış olumsuz bir olaya dayanır. Bireyler bir yandan meydana gelen olayın sebebi ya da sebepleri, diğer taraftan olayın neticesinde ortaya çıkacak olumsuz sonuçlar ve bunların kendisine etkisi hakkında mütalaalarda bulunurlar ve neticede umutsuzluk ortaya çıkar (Şahin, 2002). Değersizlik, çaresizlik, mutsuzluk, kararsızlık, eyleme geçememe, işlerini sürdürememe ve suçluluk duyguları umutsuzluğa eşlik eden duygulardır (Ăğ1r, 2004).

Travmatik yaşantılar her yaş grubundan insanları çeşitli şekillerde etkileyebilmektedir. Bu yönüyle çocuk ve ergenler de yetişkinler gibi Travma Sonrası Stres Bozukluğu belirtilerine maruz kalmaktadır (Yule, 1992). Ergenlik dönemi bireylerin travma ve TSSB'ye maruz kalmaya açık oldukları bir dönemdir. Çünkü bu dönem bireyin fiziksel ve psikososyal gelişim ve değişimlerle sürekli baş ettiği bir dönemdir. $\mathrm{Bu}$ açıdan ergenlik dönemindeki bireyler TSSB geliştirme yönünden yetişkinlere göre daha yüksek risk bir grubu olabilirler. Ergenlik dönemindeki bireyler geçmişe, bugüne ve geleceğe dönük beklentileri bir kimlik oluşturma çabasıyla birleştirmeye çalışmaktadır. Bu çaba ergenlik dönemi boyunca devam eder. Ancak travma bu süreç üzerinde bozucu etkiler oluşturur, bireyin sağlıklı kimlik gelişimini olumsuz etkiler. Ergenlerde travma sonrasinda dünya ve kendi gelecekleri hakkında olumsuz tutumlar geliştirme, kendi korkuları ve travmaya verdikleri tepkilere ilişkin endişeler, risk alma, okuldan kaçma, madde kullanım, iştah ve uyku sorunları, günlük etkinliklere 
karşı ilgi kaybı, akademik başarısızlık, anne ve babalarla çatışma gibi tepkiler gelişebilir (Cohen, 2003)

Bilindiği gibi 23 Ekim ve Kasım 2011 tarihlerinde Van'da iki yıkıcı deprem meydana geldi. Van ve Erciş'te yaşanan bu depremler onlarca öğretmenin ölmesine, birçok okulun yıkılmasına ve hasar görmesine neden oldu. $\mathrm{Bu}$ durum ortaöğretim öğrencileri üzerinde doğrudan veya dolaylı çeşitli olumsuz etkiler oluşturdu. Öğretmenlerini ve okullarını kaybetme, deprem sonrası süreçte hasarlı okullarda eğitime devam etme gibi faktörler öğrencilerin travmadan daha yüksek düzeyde etkilenmelerine zemin hazırladı. Diğer yandan umutsuzluk duygusu travmatik yaşam olaylarından sonra en yoğun yaşanan ve çeşitli olumsuz etkileri olan duygulardan biridir. Yapılan bazı çalışmalar travma sonrası dönemde ergenlerin umutsuzluk duygularını yoğun olarak yaşadıklarını göstermektedir (Artar, 2003). Bu bağlamda yaşanan depremin ortaöğretim öğrencileri üzerindeki psikolojik etkilerini fark etmek psikolojik yardım ve destek çalışmalarında büyük önem taşımaktadir.

Yukarıda belirtilenlerden hareketle bu çalışmanın amacı Van depremini ortaöğretim öğrencilerinin travmadan etkilenme ve umutsuzluk düzeylerinin incelenmesidir. $\mathrm{Bu}$ bağlamda depremi yaşayan öğrencilerin travmadan etkilenme ve umutsuzluk düzeyleri, TSSB ve umutsuzluk düzeyleri arasında nasıl bir ilişki bulunduğu, katılımcıların düşük, orta, yüksek umutsuzluk ve travmadan etkilenme düzeylerinin cinsiyet, depremde yakın kaybı yaşama ve lise türü değişkenlerine göre anlamlı bir farklılaşma gösterip göstermediği araştııılacaktır.

\section{YÖNTEM}

Yapılan bu araştırma, genel tarama modellerinden betimsel yaklaşım ve ilişkisel tarama deseni ile yürütülmüştür. Tarama modelleri, geçmişte ya da halen var olan bir durumu olduğu şekliyle betimlemeyi amaçlamaktadır. İlişkisel tarama modelleri ise iki ya da daha çok sayıdaki değişken arasındaki birlikte değişimin varlığını ve/veya derecesini belirleyen desenlerdir (Karasar, 2009).

\section{Çalışma Evreni ve Çalışma Grubu}

Araştırmanın çalışma evrenini Van depremini yaşayan ve Erciş ilçesinde farklı liselerde öğrenim gören ortaöğretim öğrencileri oluşturmaktadır. Araştırmanın çalışma grubu$\mathrm{nu}$ ise Erciş'te değişik lise türlerinde öğrenim gören 6 liseden toplam 325 öğrenci oluşturmaktadır. Bunlardan 140 katılımcı erkek, 185 katılımcı ise kadındır. Araştırmanın çalışma grubu ilçede bulunan her bir lise türünden ve sınıf düzeyinden katılımcı olacak şekilde seçkisiz olarak belirlenmiştir. Katılımclara ait betimsel veriler Tablo 1'de verilmiştir.

Tablo 1. Katılımclara Ait Betimsel Veriler

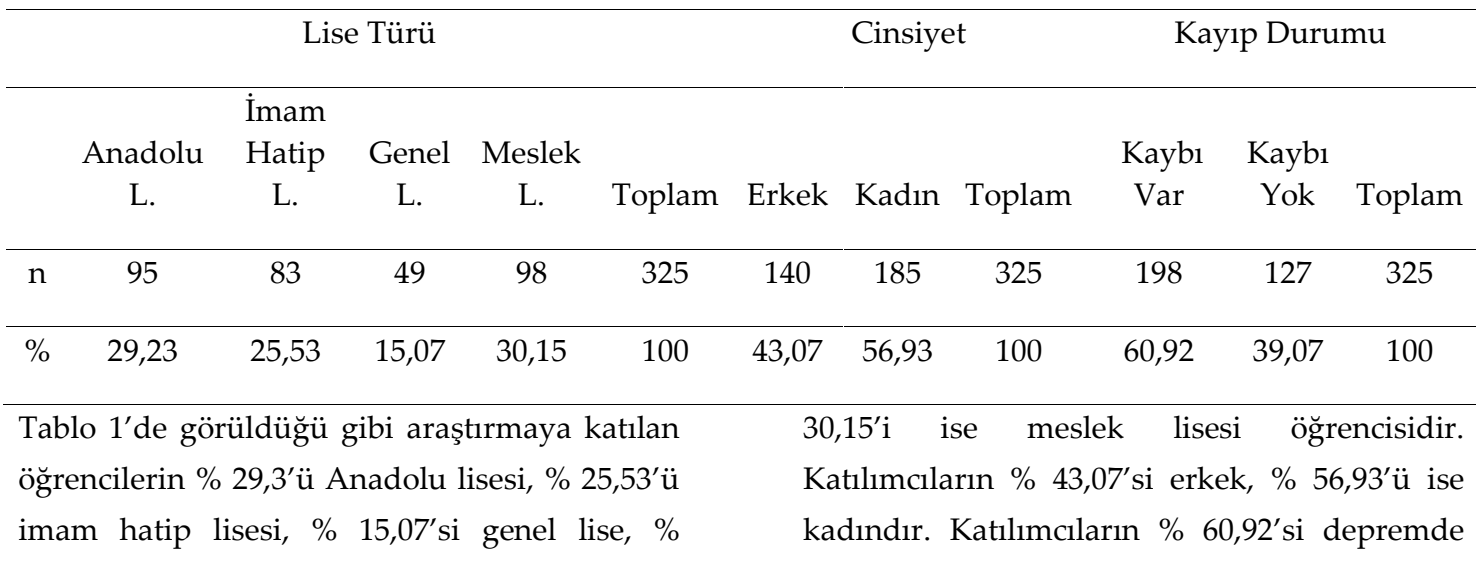


herhangi bir yakınını kaybetmiş, \% 39,07'si ise yakın kaybı yaşamadı̆̆ını belirtmiştir.

\section{Veri Toplama Araçları}

Araştırmada katılımcılara Çocuklar İçin Travma Sonrası Stres Tepki Ölçeği (ÇTSS-TÖ), Beck Umutsuzluk Ölçeği (BUÖ) ve Katılımcı Bilgi Formu uygulanmıştır. Çocuklar için travma sonrası stress tepki ölçeği (ÇTSS-TÖ) çocuk ve ergenlerde ortaya çıkan stres tepkilerini değerlendirmek için geliştirilmiş likert tipi yarı yapılandırılmış bir ölçektir. Pynoos ve ark. tarafından (1987) geliştirilmiştir. ÇTSS-TÖ 20 maddeden oluşur ve her madde belirtinin şiddetine göre 0-4 puan arasında değerlendirilir. Yüksek puan travmadan yüksek düzeyde etkilenmeyi gösterir. ÇTSS-TÖ Tü rkçe geçerlik- güvenirlik ve uyarlama çalışması Erden ve ark. (1999) tarafından yapılmıştır. Zaman içerisindeki tutarlığ1 test-tekrar test yöntemi ile sınanan ölçeğin güvenirliği 0.86, Cronbach Alfa değeri 0.75 olarak bulunmuştur. BUÖ; Beck ve ark. (1974) tarafından geliştirilmiş, bireyin geleceğe dönük umutsuzluk belirtilerini ölçen bir ölçektir. Evet ve hayır şeklinde yanıtlanan 20 maddeden oluşmaktadır. (Seber ve ark. 1993). Ölçekten alınan yüksek puanlar yüksek umutsuzluk düzeyini göstermektedir. Ölçeğin Türkçeye çevirisi Seber (1991), geçerlik ve güvenirlik çalışması ise Seber (1991) ve Durak (1993) tarafından gerçekleştirilmiştir. Seber ve ark. (1993) yaptıkları umutsuzluk ölçeğinin güvenirlik çalışmasında Cronbach alfa katsayısı $\mathrm{a}=0.86$, madde-toplam puan korelasyonlarının 0.07 ile 0.72 arasında değiştiğini, üniversite öğrencilerinde test-tekrar test güvenirliğinin .74 olduğunu bulmuşlardır.

İşlem ve Veri Analizi

Araştırmaya katılan ortaöğretim öğrencilerinin TSSTÖ ve Beck Umutsuzluk Ölçeği'nden (BUÖ) aldıkları puanlar İki Aşamalı Kümeleme (Two Step Cluster) Analizine tabi tutulmuştur. İki Aşamalı Kümeleme Analizi, heterojen yapı sergileyen bir örneklemi homojen alt gruplara bölen ve elde ettiği homojen gruplara ait betimsel değerleri ayrı bir biçimde hesaplayan çok değişkenli istatistiksel yöntemlerden biridir (Kayri 2007). Bu analiz travmadan etkilenme ve umutsuzluk puanları açısından homojen alt gruplar oluşturarak, bu grupları kendi aralarında karşılaştırma ve değerlendirme imkanı vermektedir. $\mathrm{Bu}$ bağlamda düşük düzeyde travmaya veya umutsuzluğa sahip katılımcılar yüksek düzey travma ve umutsuzluğa sahip bireylerle çeşitli değişkenler açısından incelenebilir. Bu yolla farklı düzeylerde travmadan etkilenen ve umutsuzluk düzeyleri farklılık gösteren bireylerin travmadan etkilenmeleri farklı değişkenler açısından çeşitli düzeylerde incelenebilecektir. Araştırmaya katılan öğrencilerin travma sonrası stres ve umutsuzluk puanlarının normal dağılım gösterip göstermediği Kolmogorov-Smirnov Testi ile incelenmiştir (Büyüköztürk 2009). Kolmogorov-Smirnov Testine göre travmadan etkilenme düzeyine ilişkin $(Z=1,041, P=, 229)$ cevapların normal dağılım gösterdiği, umutsuzluk puanlarının $(Z=2,397 ; P=0.000)$ normal dağılım göstermedikleri görülmüştür. $\mathrm{Bu}$ yüzden araştırmada parametrik olmayan testler kullanılmıştır.

\section{BULGULAR}

Araştırmada iki aşamalı kümeleme analizi ile çalışma grubundaki tüm uç bireylerin incelenmesi hedeflenmiştir. Öğrencilerin travmadan etkilenme ve umutsuzluk düzeylerinin belirlenmesinde daha detaylı bir sonuç elde etmek için veriler iki aşamalı kümeleme analizi ile incelenmiştir. Analiz sonucunda araştırmaya katılan öğrencilerin travmadan etkilenme ve umutsuzluk düzeyleri açısından farklı evrenlerden geldikleri görülmüştür. Buna göre travmadan etkilenme için düşük düzey, orta düzey ve yüksek düzey etkilenme olmak üzere üç farklı küme oluşmuştur. Umutsuzluk düzeyi de düşük, orta ve yüksek düzey umutsuzluk 
olmak üzere üç kümeye ayrılmıştır. Sonuçlar

tablo 2'de verilmiştir.

Tablo 2. Travma ve Umutsuzluk düzeylerinin iki aşamalı kümeleme analizi sonuçları

\begin{tabular}{ccccccccc}
\hline & \multicolumn{4}{c}{ Travma Düzeyi } & \multicolumn{5}{c}{ Umutsuzluk Düzeyi } \\
\hline Kümeler & $\mathrm{N}$ & $\%$ & $\bar{X}$ & $\mathrm{St}$ & $\mathrm{n}$ & $\%$ & $\bar{X}$ & St \\
\hline Düşük Düzey & 68 & 20,9 & 17,38 & 6,64 & 125 & 38,50 & 7,96 & 1,63 \\
\hline Orta Düzey & 153 & 47,1 & 40,27 & 6,73 & 120 & 36,90 & 3,21 & 1,32 \\
\hline Yüksek Düzey & 104 & 32 & 61,83 & 5,98 & 80 & 24,60 & 15,15 & 2,28 \\
\hline Toplam & 325 & 100 & 42,38 & 17,60 & 325 & $100 \%$ & 7,99 & 4,92 \\
\hline
\end{tabular}

Tablo 2 incelendiğinde, ikinci kümede yer alan öğrencilerin travma sonrası stres puanlarının $40,26 \pm 6,78$ olduğu görülmektedir ve bu değer, araştırmaya katılan öğrencilerin puanları açısından eşik değer olarak değerlendirilmiştir. Orta düzey travmadan etkilenen grupta 143 (\% $45,8)$ birey bulunmaktadır. Travma puanları eşik değerin üstünde olan bireyler için yüksek düzeyde travmadan etkilendikleri, düşük olan bireyler için travmatik olaydan az etkilendikleri söylenebilecektir. Buna göre birinci grupta yer alan $69(\% 22,1) \quad$ birey travmadan diğerlerine göre az etkilenmiş, üçüncü grupta yer alan 100 ( \% 32,1) birey travmadan çok etkilenmiştir.

Katılımcıların umutsuzluk düzeyleri ile ilgili analiz incelendiğinde orta düzey umutsuzluk grubunda yer alan 121 (\% 37) öğrencinin umutsuzluk puanı ortalamaları 3,21 $\pm 1,317$ olarak bulunmuş, bu değer eşik değer olarak kabul edilmiştir. Buna göre araştırma grubunda yer alan ve puan ortalamaları $7,96 \pm 1,633$ olan birinci kümedeki 125(\%38,2) birey düşük düzey umutsuzluğa, ortalamaları 15,18 \pm 2,297 olan üçüncü gruptaki 81 (\% 24,8) birey ise yüksek umutsuzluğa sahiptir.

Katılımcıların umutsuzluk düzeyleri ile travmadan etkilenme düzeyleri arasındaki ilişkiye dönük olarak yapılan korelasyon analizi sonuçlarına göre bireylerin TSSB ve BUÖ puanları arasında pozitif yönde doğrusal bir ilişki olduğu görülmektedir ( $\mathrm{r}$,395 p=0.00 $(<0,05)$ Buna göre katılımcıların umutsuzluk düzeyi arttıkça travmadan etkilenme düzeyleri de artmaktadır. Travma ve umutsuzluk düzeyleri arasındaki ilişki için ki kare testi sonuçları tablo $3^{\prime}$ te verilmiştir.

Tablo 3. Travma ve umutsuzluk düzeyleri arasındaki ilişki için ki kare testi sonuçları

\begin{tabular}{|c|c|c|c|c|c|c|}
\hline & & & \multicolumn{4}{|c|}{ Umutsuzluk } \\
\hline & & & $\begin{array}{l}\text { Düşük } \\
\text { Düzey }\end{array}$ & $\begin{array}{c}\text { Orta } \\
\text { Düzey }\end{array}$ & $\begin{array}{l}\text { Yüksek } \\
\text { Düzey }\end{array}$ & Toplam \\
\hline \multirow{8}{*}{$\begin{array}{c}\text { Travmadan Etkilenme } \\
\text { Düzeyi }\end{array}$} & \multirow{2}{*}{ Düşük Düzey } & $\mathrm{n}$ & 25 & 36 & 7 & 68 \\
\hline & & $\%$ & 36,20 & 52,20 & 11,60 & 100,00 \\
\hline & \multirow{2}{*}{ Orta Düzey } & $\mathrm{N}$ & 65 & 64 & 24 & 153 \\
\hline & & $\%$ & 40,60 & 43,40 & 16,10 & 100,00 \\
\hline & \multirow{2}{*}{ Yüksek Düzey } & $\mathrm{N}$ & 35 & 20 & 49 & 104 \\
\hline & & $\%$ & 33,00 & 20,00 & 47,00 & 100,00 \\
\hline & \multirow{2}{*}{ Toplam } & $\mathrm{N}$ & 125 & 120 & 80 & 325 \\
\hline & & $\%$ & 37,20 & 37,80 & 25,00 & 100,00 \\
\hline
\end{tabular}

$\mathrm{X}^{2}=47,87, \mathrm{df}=4, \mathrm{p}=, 0(\mathrm{p}<0.05)$.

Travmadan etkilenmenin farklı düzeyleri ile umutsuzluğun farklı düzeyleri arasındaki ilişkiye dönük Ki-kare testi sonuçlarına göre bu değişkenler arasında anlamlı bir ilişki bulun- 
maktadır. Buna göre yüksek düzey travmaya sahip bireylerin yaklaşık yarısı (\%47) aynı zamanda yüksek düzey umutsuzluğa sahiptir. Düşük düzey travmadan etkilenen katılımcıların sadece \% 11,6'sı yüksek düzey umutsuzluğa sahiptir. Katılımclların travma düzeyleri ve ilişkili değişkenler için ki kare testi sonuçları tablo 4' te verilmiştir.

Tablo 4. Travma ve ilişkili değişkenler için ki kare testi sonuçları

\begin{tabular}{|c|c|c|c|c|c|c|c|c|c|}
\hline & & \multicolumn{8}{|c|}{ Travma Düzeyi } \\
\hline & & \multicolumn{2}{|c|}{ Düşük düzey } & \multicolumn{2}{|c|}{ Orta Düzey } & \multicolumn{2}{|c|}{ Yüksek düzey } & \multicolumn{2}{|c|}{ Toplam } \\
\hline & & $\mathrm{n}$ & $\%$ & $\mathrm{n}$ & $\%$ & $\mathrm{n}$ & $\%$ & $\mathrm{n}$ & $\%$ \\
\hline \multirow[t]{3}{*}{ Cinsiyet } & $\mathrm{E}$ & 46 & 68,10 & 69 & 46,20 & 25 & 24,00 & 137 & 43,90 \\
\hline & K & 22 & 31,90 & 854 & 53,80 & 79 & 76,00 & 175 & 56,10 \\
\hline & Toplam & 68 & 100,00 & 153 & 100,00 & 104 & 100,00 & 325 & 100,00 \\
\hline \multicolumn{10}{|c|}{$\mathrm{X}^{2}=32,369, \mathrm{df}=2 \mathrm{p}=0,000(\mathrm{p}<.05)$} \\
\hline \multirow{3}{*}{$\begin{array}{l}\text { Yakın } \\
\text { kaybı }\end{array}$} & Evet & 15 & 21,70 & 62 & 43,40 & 50 & 48 & 125 & 40,10 \\
\hline & Hayır & 53 & 78,30 & 91 & 56,60 & 54 & 52 & 187 & 59,90 \\
\hline & Toplam & 68 & 100 & 153 & 100 & 104 & 100 & 325 & 100 \\
\hline \multicolumn{10}{|c|}{$\mathrm{X}^{2}=11,94, \mathrm{df}=2 \mathrm{p}=, 003(<.05)$} \\
\hline \multirow{5}{*}{$\begin{array}{l}\text { Lise } \\
\text { Türü }\end{array}$} & Genel & 15 & 21,70 & 21 & 14,00 & 13 & 12 & 47 & 15,10 \\
\hline & $\begin{array}{c}\text { Meslek } \\
\text { Lisesi }\end{array}$ & 21 & 30,40 & 52 & 36,40 & 25 & 25 & 98 & 31,40 \\
\hline & Anadolu & 23 & 34,80 & 43 & 27,30 & 29 & 27 & 90 & 28,90 \\
\hline & $\begin{array}{l}\text { İmam } \\
\text { Hatip }\end{array}$ & 9 & 13,00 & 37 & 22,40 & 37 & 36 & 77 & 24,70 \\
\hline & Toplam & 68 & 100 & 153 & 100 & 104 & 100 & 325 & 100 \\
\hline
\end{tabular}

Tablo 4 incelendiğinde travmadan etkilenmenin üç farklı düzeyi ile cinsiyet arasında KiKare testi sonucunda anlamlı bir ilişkinin olduğu belirlenmiştir $(\mathrm{p}<.05)$. Katılımcılardan travmadan düşük düzeyde etkilenenlerin \% 68,1'ini erkek öğrenciler, \% 31, 9'unu k1z öğrenciler, orta düzeyde etkilenenlerin \% 46, 2'sini erkek öğrenciler, \% 53, 8'ini kız öğrenciler, yüksek düzeyde travmadan etkilenenlerin \% 24'ünü erkek öğrenciler \% 76'sını kız öğrenciler oluşturmaktadır.

Tablo 4'te travma ile depremde yakın kaybı yaşama arasındaki ilişkiye bakılınca Ki-kare testi sonucuna göre yakın kaybı yaşama ile travmadan farklı düzeyde etkilenme arasında anlamlı bir ilişki bulunmaktadır ( $\mathrm{p}<.05)$. Analiz sonuçlarına göre travmadan düşük düzeyde etkilenenlerin \% 21,7 'si yakın kaybı yaşayan- lar, \% 78,3’ü yakın kaybı olamayanlar, orta düzeyde etkilenenlerin \% 43,4'ü yakın kaybı yaşayanlardan, \% 56,6'sı yakın kaybı olmayanlar, yüksek düzeyde etkilenenlerden \% 48'i yakın kaybı olanlar, \% 52'si yakın kaybı olmayanlardan oluşmaktadır.

Buna göre travmadan etkilenme düzeyi yükseldikçe yakın kaybı yaşayanların sayısı ve yüzdesi düşmekte, travmadan etkilenme düzeyi yükseldikçe yakın kaybı olanların sayısı ve yüzdesi artmaktadır. Bu da yakın kaybı yaşayanların daha çok yüksek düzeyde, kayıp yaşamayanların ise daha çok düşük düzeyde travmadan etkilendiklerini göstermektedir.

Travmadan etkilenme ile ilişkili diğer bir değişken ise lise türüdür. Farklı lise türleriyle travmadan farklı düzeylerde etkilenme arasında anlamlı bir ilişki olup olmadığı ile ilgili 
yapılan Ki-kare analizi sonuçlarına göre lise türü ile travmadan farklı düzeylerde etkilenme arasında anlamlı bir ilişki bulunmaktadır $(p=.05)$. Bulgulara göre düşük düzeyde etkilenenler arasında en küçük grup imam hatip lise öğrencileri iken (\%13), en büyük grup Anadolu lisesi öğrencileridir $(\% 34,8)$. Yüksek düzeyde etkilenenlerden ise en büyük grup imam hatip lisesi öğrencileri, en küçük grup ise genel lise öğrencileridir. Buna göre imam hatip lisesi öğrencileri diğerlerine göre travmadan daha yüksek düzeyde etkilenmiş denilebilir.

Katılımcıların umutsuzluk düzeyi ve onunla ilişkili değişkenlere dönük $\mathrm{ki}$ kare testi sonuçları tablo 5 'te verilmiştir.

Tablo 5. Umutsuzluk düzeyi ve onunla ilişkili değişkenlere dönük ki-kare testi sonuçları

\begin{tabular}{|c|c|c|c|c|c|c|c|c|c|}
\hline & & \multicolumn{2}{|c|}{ Düşük Düzey } & \multicolumn{2}{|c|}{ Orta Düzey } & \multicolumn{2}{|c|}{ Yüksek Düzey } & \multicolumn{2}{|c|}{ Toplam } \\
\hline & & $\mathrm{n}$ & $\%$ & $\mathrm{~N}$ & $\%$ & $\mathrm{n}$ & $\%$ & $\mathrm{n}$ & $\%$ \\
\hline \multirow[t]{3}{*}{ Cinsiyet } & $\mathrm{E}$ & 57 & 45,60 & 57 & 47,90 & 26 & 33,30 & 142 & 43,40 \\
\hline & K & 68 & 54,40 & 63 & 52,10 & 54 & 66,70 & 185 & 56,60 \\
\hline & Total & 125 & 100 & 120 & 100 & 80 & 100 & 325 & 100 \\
\hline \multicolumn{10}{|c|}{$\mathrm{X}^{2}=4,93, \mathrm{df}=2, \mathrm{p}=0,085(\mathrm{p}>0.05)$} \\
\hline \multirow[t]{3}{*}{ Yakın kaybı } & Var & 54 & 43,20 & 39 & 32,20 & 34 & 42 & 127 & 38,80 \\
\hline & Yok & 71 & 56,80 & 81 & 67,80 & 46 & 58 & 200 & 61,20 \\
\hline & Toplam & 125 & 100 & 120 & 100 & 80 & 100 & 325 & 100 \\
\hline \multicolumn{10}{|c|}{$\mathrm{X}^{2}=3,467, \mathrm{df}=2 \mathrm{p}=0,177(\mathrm{p}>0.05)$} \\
\hline \multirow[t]{5}{*}{ Lise türü } & Genel lise & 25 & 20,00 & 14 & 12,40 & 10 & 12,30 & 50 & 15,30 \\
\hline & Meslek 1 & 36 & 28,80 & 47 & 38,80 & 15 & 18,50 & 98 & 30,00 \\
\hline & Anadolu & 29 & 23,5 & 41 & 33,90 & 25 & 32,10 & 96 & 29,30 \\
\hline & İmam Hatip & 35 & 28 & 18 & 14,90 & 30 & 37.0 & 83 & 25,40 \\
\hline & Toplam & 125 & 100 & 120 & 100 & 80 & 100 & 325 & 100 \\
\hline \multicolumn{10}{|c|}{$\mathrm{X}^{2}=22,710, \mathrm{df}=6 \mathrm{p}=0,001(\mathrm{p}<0.05)$} \\
\hline
\end{tabular}

Tablo 5'te katılımciların umutsuzluk düzeylerinin cinsiyeti depremde kayıp yaşama durumu ve lise türüne göre dağılımları ve Ki-kare testi sonuçları verilmiştir. Sonuçlara göre cinsiyet değişkeni ile umutsuzluğun farklı düzeyleri arasında anlamlı bir ilişki bulunamamıştır $(\mathrm{p}>.05)$. $\mathrm{Bu}$ sonuçlara göre düşük ve orta düzeylerde büyük farklılıklar görünmezken, yüksek düzey umutsuzlukta kadınların erkeklere göre önemli ölçüde farklılaştıkları, yani umutsuz oldukları gözlenmektedir.

Umutsuzluk düzeyleri ile kayıp durumu arasındaki ilişkiye bakıldığında yakın kaybının umutsuzluğun farklı düzeylerini anlamlı yordayan değişkenlerden biri olmadığı görülmektedir ( $\mathrm{p}>.05)$. Umutsuzlukla ilgili son değişken lise türü değişkenidir. Buna göre lise türü farklı umutsuzluk düzeyleri ile anlamlı bir ilişkiye sahiptir $(\mathrm{p}<.05)$. Buna göre yüksek umutsuzluk düzeyinde en üstte yer alan grup imam hatip lisesi öğrencileridir. Bu durum imam hatip lisesi öğrencilerinin diğgerlerine göre daha umutsuzluk oldukları söylenebilir. $\mathrm{Bu}$ durum imam hatip lisesinden çalışmaya katılanların hepsinin kız öğrenci olmasından kaynaklanıyor olabilir.

\section{TARTIŞMA VE SONUÇ}

Araştırma sonuçlarına göre travmadan etkilenme ile umutsuzluk düzeyi arasında pozitif yönde anlamlı bir ilişki bulunmaktadır. 
Buna göre travmadan etkilenme düzeyi yükseldikçe umutsuzluk düzeyi de yükselmektedir. Araştırmanın bu bulgusu konu ile ilgili yapılan diğer bazı çalışmalarla paralellik göstermektedir (Scher ve Resick 2005; Artar 2003, Ehtiyar ve Üngüren, 2009). Umutsuzluk ve travmanın beraber çalışıldığı bir araştırmada umutsuzluğun TSSB ile korelasyon içinde olduğu ve TSSB için bir risk faktörü olduğu belirlenmiştir. Ancak umutsuzlukla travma arasında nedensel bir ilişkiye rastlanmamıştır (Scher ve Resick, 2005). Deprem sonrası ergenlerin gelecek beklentilerini inceleyen başka bir araştırmaya göre ergenlerin geleceğe dönük yüksek beklentiler içinde olup, bu beklentileri gerçekleştirme konusunda umutsuz olmaları onların bu travmatik yaşantı sonrasında bir değişim yaşadıklarını, beklentilerinin gerçekleşmesi konusunda umutsuzluğa düştüklerini göstermektedir (Artar 2003). Umutsuzluk ve travmatik yaşantılar arasındaki ilişki ile ilgili başka bir çalışmada da travmatik yaşantıların umutsuzluk düzeyini anlamlı şekilde yordadığı, travmatik yaşantılar arttıkça umutsuzluk düzeyinin de yükseldiği belirlenmiştir (Ehtiyar ve Üngüren, 2009). Bu sonuçlara göre umut ve umutsuzluk travmatik yaşam olaylarında ve bunlara müdahale çalışmalarında oldukça önemli değişkenlerdir.

Araştırmada travmayla bağlantısı incelenen diğer bir değişken de cinsiyettir. Travmadan farklı düzeylerde etkilenmenin cinsiyet açısından ele alındığı bu çalışmada yapılan analizlerin sonuçlarına göre kı öğrenciler erkeklere göre daha fazla yüksek düzey travma yaşamaktadır. Bu bağlamda kadınlar erkeklere göre daha fazla travmadan yüksek düzeyde etkileniyor denilebilir. Bu da cinsiyet değişkenin travmatik yaşam olaylarından etkilenme düzeyini açıklamada önemli bir değişken olduğunu göstermektedir. Bu sonuç daha önce yapılan bazı araştırma bulgularıyla paralellik göstermektedir (North Oliver ve Pandya, 2012; Baloğlu Harris ve Karagözoğlu, 2005; Dell'Osso ve ark, 2013). Udwin ve ark. (2000) ergenler için afet sonrası uzun dönemde TSSB için risk faktörlerini belirlemek amacıyla yaptıkları çalışmada cinsiyet TSSB için anlamlı bir değişken olarak bulunmuştur. Buna göre kadın olmak TSSB geliştirme konusunda bir risk faktörüdür. Diğer bazı araştırmalarda da kadın olmanın TSSB için bir risk faktörü olduğu, kadınların travmadan etkilenme düzeyinin erkeklerden daha yüksek olduğu sonucuna ulaşılmıştır (Pynoos ve ark., 1993; Green ve ark., 1991; Karakaya ve ark., 2004)

Araştırmada travma düzeyiyle ilişkili değişkenlerden biri de katılımcların depremde yakınlarından birini kaybetme durumlarıdır. Araştırma bulgularına göre yakın travmadan etkilenme düzeyi yakın kaybı yaşayıp yaşamama durumuna göre anlamlı farklılaşma göstermektedir. Buna yakın kaybı yaşayanların yüksek düzeyde travmadan etkilenme oranları daha fazladır. Konu ile ilgili yapılan benzer bir araştırmada depremde yakın kaybı yaşama umutsuzlukla ilişkili bir değişken olarak bulunurken, travmayla belirgin şekilde ilişkili bir değişken olarak bulunmamıştır. Ani yakın kaybı yaşama travmayı algılamada anlamlı bir değişken olarak bulunmamıştır (Dizer, 2008).

Araştırmanın sorularından birisi de travmadan etkilenme düzeyinin lise türüne göre anlamlı bir değişme gösterip göstermediğidir. Sonuçlara göre travma düzeyi lise türüne göre anlamlı şekilde farklılaşmaktadır. Konu ile ilgili Marmara depreminden sonra ergenler üzerinde yapılan bir çalışmanın sonucuna göre düz lise ve meslek lise öğrencilerinin travma algıları Anadolu lisesi öğrencilerine göre daha yüksek çıkmıştır (Dizer, 2008). Bu çalışmada ise imam hatip lisesi öğrencileri travmadan en yüksek düzeyde etkilenen grup çıkmıştır. Ancak bu sonucun lise türünden daha çok cinsiyetle 
ilişkili bir değişken olduğu düşünülmektedir. Çünkü imam hatip lisesinden araştırmaya katılan öğrencilerin bütünü kız öğrenciydi. Araştırmada kı öğrencilerinin travma düzeylerinin erkeklere göre anlamlı şekilde yüksek olduğu göz önünde bulundurulduğunda imam hatip lisesi öğrencilerinin travma düzeylerinin yüksek çıkması bu durumun bir sonucu olarak düşünülebilir.

Araştırmanın amaçlarından biri de katılımcıların umutsuzluk düzeylerinin cinsiyet, yakın kaybı yaşama ve lise türü değişkenlerine göre anlamlı farklılaşma gösterip göstermediğidir. Yapılan analizlere göre umutsuz düzeyiyle ilişkili tek değişken lise türü olarak bulunmuştur. Çalışmada kız öğrencilerin umutsuzluk düzeyleri erkeklere göre daha yüksek çıkmıştır. Ancak umutsuzluğun farklı düzeyleri arasında cinsiyete göre anlamlı bir farklılaşma görünmemektedir. Konu ile ilgili yapılan çalışmalarda umutsuzluk düzeylerinin cinsiyete göre farklılaştığına yönelik bulgular olduğu gibi (Üngüren ve Ehtiyar, 2009, Girgin 2009, Dizer, 2008) , umutsuzlukla cinsiyet arasinda herhangi bir ilişki bulunmadığına yönelik bulgular da mevcuttur (Tekin ve Filiz, 2008). Bazı araştırmalarda erkeklerin umutsuzluk düzeyi daha yüksek olarak bulunurken (Bolland, 2003; Özmenve ark., 2008; Oğuztürk ve ark., 2011; Çelikel ve Erkorkmaz, 2008) bazılarında kadınların umutsuzluk düzeyi daha yüksek olarak bulunmuştur (Mazza ve Reynolds, 1998).

Depremde yakın kaybı yaşama da travma düzeyiyle bağlantılı bir değişken olarak bulunmamıştır. Ancak ergenlerle yapılmış olan benzer bir çalışmaya göre yakın kaybı yaşayanların umutsuzluk düzeyleri yaşamayanlara göre belirgin şekilde farklılaşmaktadır (Dizer, 2008).
Lise türü değişkeni umutsuzluk düzeyiyle anlamlı ilişkiye sahip bir değişken olarak bulunmuştur. Buna göre umutsuzluk düzeyleri lise türüne göre anlamlı farklılaşma göstermektedir. Ergenlerle ilgili yapılan benzer çalışmada umutsuzluk düzeyinin lise türüne göre farklılaşmadığına ulaşılmıştır (Dizer 2008). Yukarıda travma ile lise türü arasındaki ilişkiye ilişkin bulguda belirtildiği gibi bu sonucun da cinsiyetle ilişkili olduğu düşünülmektedir. Çünkü araştırmada kız öğrencilerin umutsuzluk düzeyleri erkeklere göre daha yüksek olarak bulunmuştur.

$\mathrm{Bu}$ çalışmada ulaşılan bulgular travmatik yaşam olaylarına ve umutsuzluğa psikolojik müdahalede göz önünde bulundurulması gereken önemli sonuçlardır. Bu bulgulara göre kadın olma, yakın kaybı yaşama travmadan etkilenme açısından risk faktörleri arasındadır. $\mathrm{Bu}$ bağlamda travmatik olaylar sonrası yapılacak psikolojik müdahalelerde, travmaya müdahale ile ilgili ruh sağllğı politikalarını oluştururken bu faktörlerin göz önünde bulundurulması gerekir. Diğer yandan deprem sonrası umutsuzluk düzeyinin travma, cinsiyet ve travmatik olaylarda yakın kaybı yaşama değişkenleriyle ilişkisine ilişkin daha fazla çalışmaya ihtiyaç duyulmaktadır. Yukarıda ulaşılan bulgular Van depremi sonrası ulaşılan lise öğrencileriyle sınırlıdır. Bu bağlamda benzer çalışmalar, aynı ya da farklı değişkenlerle farklı bölgelerde, farklı travmatik yaşantılardan sonra, farklı yaş gruplarıyla gerçekleştirilebilir. Bu şekilde travma ve umutsuzluk kavramlarıyla ilişkili değişkenler, risk faktörleri, koruyucu faktörler ortaya çıarılabilecektir. Bu da ruh sağlığı açısından önemli avantajlar sağlayacaktır. 


\section{Kaynakça}

Abramson, L. Y., Metalsky, G. I., \& Alloy, L. B. (1989). Hopelessness depression: A theory-based subtype of depression. Psychological review, 96(2), 358.

Ağır, M. (2007). Üniversite ögrencilerinin bilişsel çarpıtma düzeyleri ile problem çözme becerileri ve umutsuzluk düzeyleri arasındaki ilişki. Yayınlanmamış Doktora Tezi, İstanbul Üniversitesi Sosyal Bilimler Enstitüsü,İstanbul.

Artar, M. ( 2003) Depremi yaşayan ergenlerin gelecek beklentilerinin içeriği, Kriz Dergisi. 11(3), 21-27.

Baloğlu, M.; Harris, M. B. \& Karagözoğlu, C., (2005). The psychological effects of an earthquake on Turkish college students, Hasan Ali Yücel Eğitim Fakültesi Dergisi. 2(2), 125-136.

Beck, A. T. (1964). Thinking and depression: II. Theory and therapy. Archives of general psychiatry, 10(6), 561-571.

Beck, A.; Wissman, A., Lester, D. \& Trexler, L. (1974). The measurement of pessimizm: The hopelessness scale. Journal of Consulting and Clinical Psychology, 42(6), 861-865.

Bolland, J. M. (2003). Hopelessness and risk behaviour among adolescents living in high-poverty innercity neighborhoods. Journal of Adolescence. 26 (2003), 145-158.

Cam Celikel, F., \& Erkorkmaz, U. (2008). Üniversite Öğrencilerinde Depresif Belirtiler ve Umutsuzluk Düzeyleri ile İlişkili Etmenler. Archives of Neuropsychiatry/Noropsikiatri Arsivi, 45(4), 122-129.

Cohen, J. A. (2003). Treating acute posttraumatic reactions in children and adolescents. Biological Psychiatry, 53(9), 827-833.

Dell'Osso L.; Carmassi, C.; Massimetti, G.; Stratta, P.; Riccardi, I.; Capanna, C.; Akiskal, K. K.; Akiskal, H. S. \& Rossi, A. (2013). Age, gender and epicenter proximity effects on post-traumatic stress symptoms in L'Aquila 2009 earthquake survivors. Journal of Affective Disorders. 146(2), 174-180.

Dizer, D. (2008). Sakarya ilindeki liseli ergenlerin 1999 marmara depremi sonrası travmayı algılama, sosyal destek sistemleri ve umutsuzluk belirtilerinin incelenmesi. Maltepe Üniversitesi Sosyal Bilimler Enstitüsü, Yayımlanmamış Yüksek Lisans Tezi. İstanbul.

Doğan, A. (2011). Adolescents' posttraumatic stres reactions and behavior problems following Marmara earthquake, European Journal of Psychotraumatology. 2, 5825-5834.

DSM-IV TR (2007). Tanı ölçütleri başचuru kitabı, (Çev. E. Köroğlu). Ankara: Hekimler Birliği Yayınları.

Durak, A. (1994). Beck umutsuzlık ölçeği: geçerlik ve güvenirlik çalışması. Türk Psikoloji Dergisi, 9(3), 111

Ehtiyar, R. \& Üngüren, E. (2009). Türk ve Alman öğrencilerin umutsuzluk düzeylerinin karşılaştırılması ve umutsuzluk düzeylerini etkileyen faktörlerin belirlenmesi: turizm eğitimi alan öğrenciler üzerinde bir araştırma. Journal of Yaşar University, 4(14), 2093-2127.

Erden, G.; Kılıç, E. Z.; Uslu, R. \& Kerimoğlu, E. (1999.) Çocuklar için travma sonrası sress tepki ölçeği: Türkçe geçerlilik, güvenilirlik ön çalışması. Çocuk ve Gençlik Ruh Să̆liğı Dergisi, 6(3), 143-149.

Girgin, G. (2009). Evaluation of the factors affecting loneliness and hopelessness among university students in Turkey. Social Behavior And Personality, 37(6), 811-818.

Green, B. L., Korol, M., Grace, M. C., Vary, M. G., Leonard, A. C., Gleser, G. C., \& Smitson-Cohen, S. (1991). Children and disaster: Age, gender, and parental effects on PTSD symptoms. Journal of the American Academy of Child \& Adolescent Psychiatry, 30(6), 945-951.

Herman, J. L. (1992). Travma ve iyileşme, (Çev: Tamer Tosun). Literatür Yayınları, İstanbul.

Karakaya, I.; Ağaoğlu, B.; Çoşkun, A.; Şişmanlar, Ş. G. \& Yıldız-Öc, Ö. (2004). Marmara depreminden üç buçuk yıl sonra ergenlerde TSSB, depresyon ve anksiyete belirtileri. Türk Psikiyatri Dergisi. 15(4), 257-263. 
Karasar, N. (2009). Bilimsel Araştırma Yöntemi. Anakara: Nobel Yayın Dağıtım.

Kayri, M. (2007). Araştırmalarda iki aşamalı kümeleme analizi ve bir uygulaması. Eğitim Araştırmaları Dergisi. 28(1), 177-189.

Ma, X.; Liu, X.; Hu, X .; Qiu, C.; Wang, Y.; Huang, Y.; Wang, Q.; Zhang, W. \& Li, T. (2011). Risk indicators for post-traumatic stress disorder in adolescents exposed to the 5.12 Wenchuan earthquake in China. Psychiatry Research. 189(3), 385-391.

Mazza, J. J., \& Reynolds, W. M. (1998). A longitudinal investigation of depression, hopelessness, social support, and major and minor life events and their relation to suicidal ideation in adolescents. Suicide and Life-Threatening Behavior, 28(4), 358-374.

Metalsky, G. I.; Joiner, T. E.; Hardin, T. S. \& Abramson, L. Y. (1993). Depressive reactions to failure in a naturalistic setting: A test of the hopelessness and self-esteem theories of depression. Journal of Abnormal Psychology, 102(1), 101.

North, C. S., Oliver, J., \& Pandya, A. (2012). Examining a comprehensive model of disaster-related posttraumatic stress disorder in systematically studied survivors of 10 disasters. American journal of public health, 102(10), 40-48.

Oğuztürk, Ö.; Akça, F. \& Şahin, G. (2011). Üniversite öğrencilerinde umutsuzluk düzeyi ile problem çözme becerileri arasındaki ilişkinin bazı değişkenler üzerinden incelenmesi. Klinik Psikiyatri. 14, 173-184.

Özgen, F. \& Aydın, H. (1999). Travma Sonrası Stres Bozukluğu. Klinik Psikiyatri. 1, 34-41.

Özmen, D., Dündar, P. E., Çetinkaya, A. Ç., Taşkın, O., \& Özmen, E. (2008). Lise öğrencilerinde umutsuzluk ve umutsuzluk düzeyini etkileyen etkenler.Anadolu Psikiyatri Dergisi, 9(1), 8-15.

Pynoos, R. S., Frederick, C., Nader, K., Arroyo, W., Steinberg, A., Eth, S. \& Fairbanks, L. (1987). Life threat and posttraumatic stress in school-age children. Archives of general psychiatry, 44(12), 10571063

Pynoos, R. S., Goenjian, A., Tashjian, M., Karakashian, M., Manjikian, R., Manoukian, G. \& Fairbanks, L. A. (1993). Post-traumatic stress reactions in children after the 1988 Armenian earthquake. The British Journal of Psychiatry,163(2), 239-247.

Sabuncuoğlu, O.; Çevikaslan, A. \& Berkem, M. (2003). Marmara depreminden etkilenen iki ayrı bölgede ergenlerde depresyon, kaygı ve davranış. Klinik Psikiyatri. 6, 189-197.

Şahin, A. (2002). İlahiyat fakültesi öğrencilerinin umutsuzluk düzeyleri üzerine bir araştırma. Selçuk Üniversitesi İlahiyat Dergisi. 13, 143-157.

Scher, C. D. \& Resick, P. A. (2005). Hopelessness as a risk factor for post-traumatic stress disorder symptoms among interpersonal violence survivors. Cognitive Behaviour Therapy. 34(2), 99-107)

Seber, G., Dilbaz, N., Kaptanoğlu, C., \& Tekin, D. (1993). Umutsuzluk ölçeği: geçerlilik ve güvenirliği. Kriz Dergisi, 1(3), 139-142.

Silbert, K. L. \& Berry, G. L. (1991). Psychological effects of a suicide prevention unit on adolescents' level of stress, anxiety, and hopelessness. Counseling and Psychology Quarterly. 4 (1), 45-59.

Tekin, M. \& Filiz, K. (2008). Beden eğitimi ve spor yüksekokullarının antrenörlük eğitimi ve spor yöneticiliği bölümlerinde öğrenim gören öğrencilerin umutsuzluk ve boyun eğici davranış düzeylerinin çeşitli değişkenlere göre incelenmesi. Spormetre, Beden Eğitimi ve Spor Bilimleri Dergisi. 6(1), 2737.

Tuna, A. K.; Parin, S. \& Tanhan, F. (2012). Van depremi sosyo-ekonomik ve psikolojik durum tespit raporu. Çocuk Vakfı Yayınları No:15., İstanbul. 
Udwin, O., Boyle, S., Yule, W., Bolton, D., \& O'Ryan, D. (2000). Risk Factors for Long-term Psychological Effects of a Disaster Experienced in Adolescence: Predictors of Post Traumatic Stress Disorder. Journal of Child Psychology and Psychiatry, 41(8), 969-979.

Yerlikaya, İ. (2006). Bilişisel-davranışçı yaklaşıma ve hobi terapiye dayalı umut eğitimi programlarının ilköğretim öğrencilerinin umutsuzluk düzeyine etkisi. Yayınlanmamış Doktora Tezi, Ankara Üniversitesi Eğitim Bilimleri Enstitüsü, Ankara.

Yüksel, Ş. (2000). Felakete uyum ve ruh sağlığı. Klinik Psikiyatri. 3, 5-11.

Yüksel, Ş. (2009). Travmatik yaraların açığa çıkmasında ve onarılmasında görüşme ortamı. Klinik Gelişim 22(4), 11-17.

Yule, W. (1992). Posttraumatic stress disorder in child survivors of shipping disasters: the sinking of the Jupiter. Psychotherapy and Psychosomatics. 57, pp. 200-205.

\section{Extended Abstract}

Traumatic life events and their psychological effects is one of the widely studied and important issue in the field of mental health. It was found that earthquakes, wars, accidents and various natural disasters have serious short and long term effects on the people. Determining individuals' reactions to the traumatic events and increasing awareness about the variables that are related with these reactions are important to be prepared for traumatic events and to develop effective intervention programs. In this context the purpose of this study is investigating trauma and hopelessness levels of high school students experiencing the Van earthquake in terms of gender, having loss after the earthquake and type of high school variables.

The study was carried out with general and relational screening model. The research population was constituted of high school students exposed to the Van earthquake from different types of high schools in the district of Erciş as one of the centers of the earthquake. The sample of the study consists of 325 students (140 male, 185 female) studying 6 different types of high schools in Erciş. In the study Child Posttraumatic Stress Reaction Index (CPTS-RI), Beck Hopelessness Scale (BHS) and an information form were used for data collection. CPTS-RI is a Likert type scale which was developed by Pynoos et al. (1987) and aims at evaluating posttraumatic stress reactions in children and adolescents. Validityreliability and Turkish adaption study of this scale were made by Erden et all. (1999). The overtime consistency of the scale was tested with test-retest method by which reliability was found as 0.86 and Cronbach's alpha value was 0.75. BHS is a scale which was developed by Beck et all. (1974) and aims at measuring individuals' hopelessness symptoms toward the future. It is answered in the form of yes-no and higher scores shows higher level of hopelessness. Validity and reliability study of the scale was made by Seber et all. (1993). In the reliability study of the BHS Cronbach's alpha values was found as 0.86 , item-total correlations as ranged between 0.07 and 0.72 , and test-retest reliability as 0.74 among university students.

When testing with Kolmogorov-Smirnov test it was found that PTSD scores shows a normal distribution and BHS scores does not show normal distribution. For this reason non parametric analysis methods were used. In data analysis chi-square test, two-step cluster analysis and spearman rho correlation analysis were used. Two step cluster analysis is one of the multivariate statistical methods which divides a heterogeneous-structure sample into homogeneous subgroups and calculation descriptive values of these homogeneous subgroups differently (Kayri, 2007). This analysis gives the opportunity to create 
homogeneous subgroups in terms of trauma and hopelessness scores and comparing and evaluating these groups among themselves.

It is found that participants' level of trauma has a significant positive relationship with their hopelessness levels. Participants' low level, medium level and high levels of trauma were found to be significantly related with the variables of being female, having loss of family members in the earthquake and type of high school. Besides participants' low level, medium level and high levels of hopelessness level was found to be significantly related to the participants' trauma levels and type of high school, but any significant relation was not found between the variable of having loss of relatives and level of hopelessness. In the research female participants' level of hopelessness was found as higher than males but a significant differentiation between different levels of hopelessness in terms of gender was not found.

It was found that variables of hopelessness, gender, loss of relatives after the earthquake are among risk factors in terms of level of being effected from the trauma.

According to different research results hopelessness was found as a risk factor for trauma. In this context, it is important for trauma victims to have feeling of hope as a coping variable for negative effects of traumatic life events. Gender is one of the significant variables in explaining level of trauma. According to the results another factor related with high level of trauma is having loss after the earthquake. It was found that trauma victims having loss are likely to be more affected from the trauma.

The findings of this study are important outcomes that should be taken into consideration in psychological intervention to traumatic life events and hopelessness. According to these findings being female and having loss because of trauma are risk factor for level of being affected form the traumatic events. In this context these factors should be taken into consideration in planning posttraumatic psychological interventions and in planning mental health policies. On the other hand there is a need for more researches related to the relation between hopelessness level after an earthquake and trauma, gender and having loss variables. 